\title{
An Empirical Investigation of Oil-Macro-Financial Linkages in Saudi Arabia
}




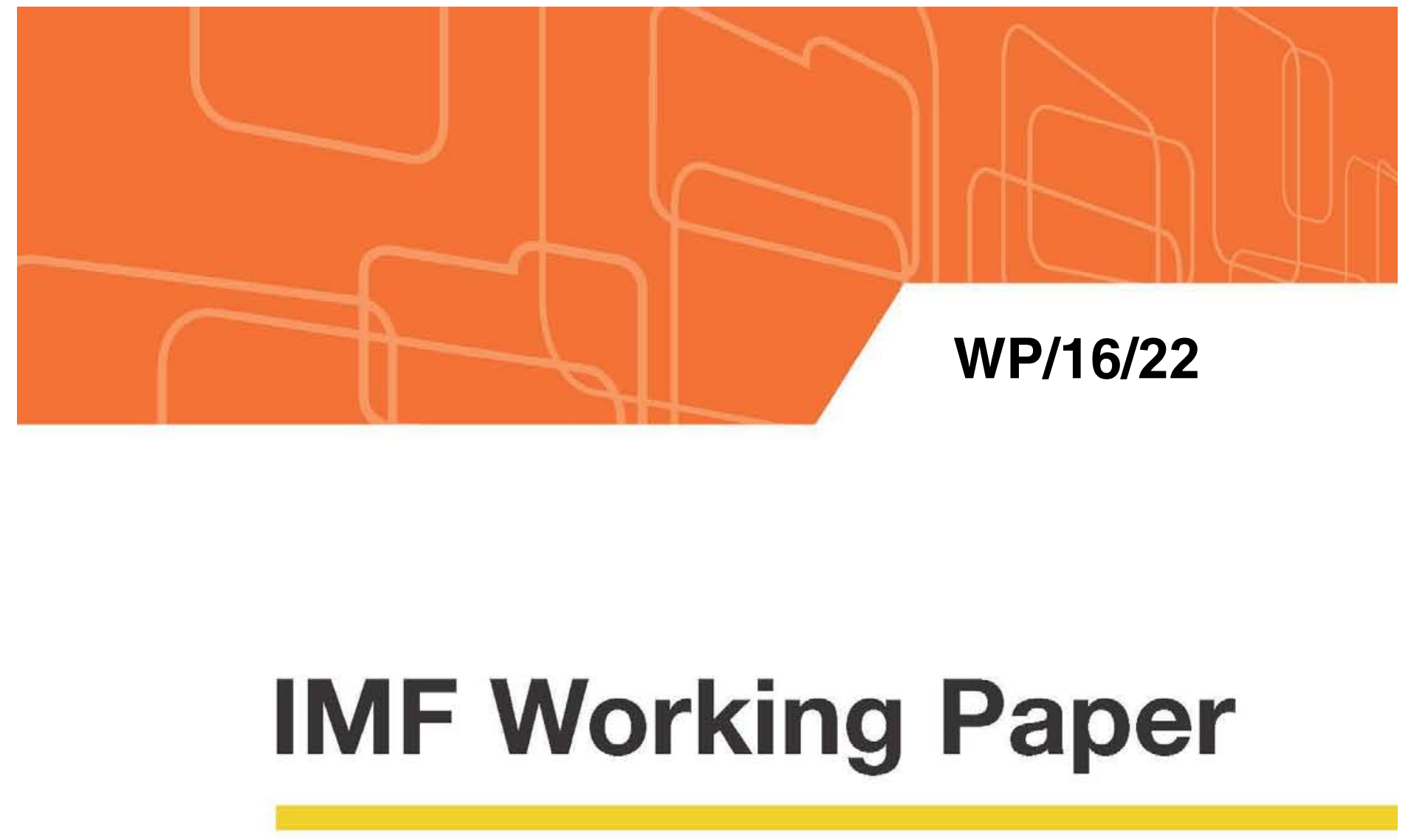

An Empirical Investigation of Oil-Macro-Financial Linkages in Saudi Arabia

By Ken Miyajima

I N T E R N A T I O N A L M O N E T A R Y F U N D 


\title{
IMF Working Paper
}

Middle East and Central Asia

\section{An Empirical Investigation of Oil-Macro-Financial Linkages in Saudi Arabia Prepared by Ken Miyajima}

\author{
Authorized for distribution by Tim Callen ${ }^{1}$
}

February 2016

\section{IMF Working Papers describe research in progress by the author(s) and are published to elicit comments and to encourage debate. The views expressed in IMF Working Papers are those of the author(s) and do not necessarily represent the views of the IMF, its Executive Board, or IMF management.}

\begin{abstract}
Oil-macro-financial linkages in Saudi Arabia are analyzed by applying panel econometric frameworks (multivariate and vector autoregression) to maceoeconomic and bank-level balance sheet data for 9 banks spanning 1999-2014. Lower growth of oil prices and nonoil private sector output leads to slower credit and deposit growth and higher nonperforming loan ratios, with feedback loops within bank balance sheets which in turn dampens economic activity. U.S. interest rates are not found to be a key determinant.
\end{abstract}

JEL Classification Numbers: C63, E44, G21, G28

Keywords: Macro-financial linkages, nonperforming loans, panel vector autoregression Author's E-Mail Address: kmiyajima@imf.org

\footnotetext{
${ }^{1}$ This paper extends “Assessing the Resilience of Saudi Banks to Weaker Economic Conditions" published in IMF Country Report No. 15/286. This and earlier versions of this paper benefitted from extensive discussion with the Executive Directors and Saudi Arabian Monetary Agency staff. The author is grateful to Tim Callen, Javier Hamann, Phakawa Jeasakul, Padamja Khandelwal, Ananthakrishnan Prasad and seminar participants at the IMF and the Saudi Arabian Monetary Agency. Any errors are the author's responsibility.
} 


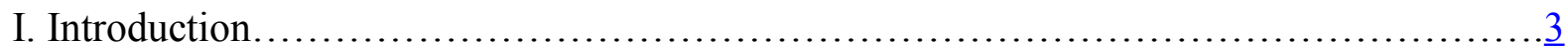

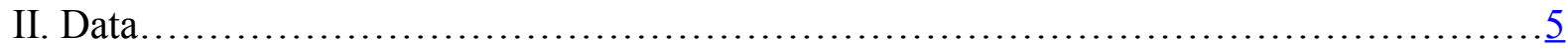

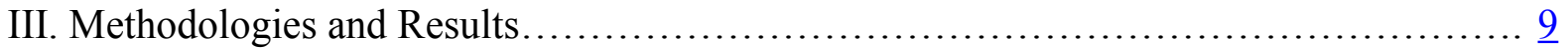

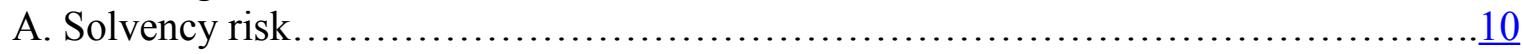

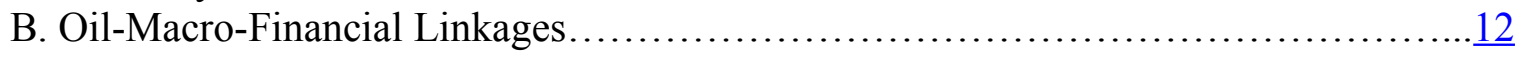

IV. Robustness .............................................................. 14

A. Different Variable Ordering.......................................................

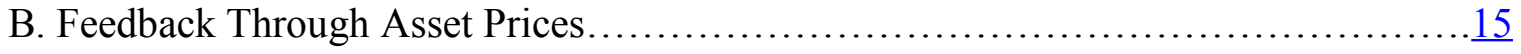

V. Conclusion..............................................................

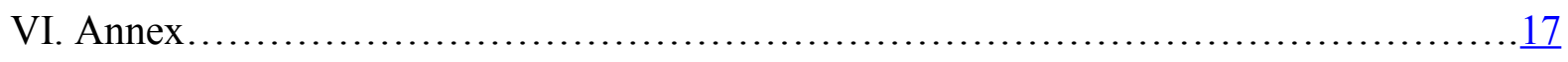

References..............................................................

Figures

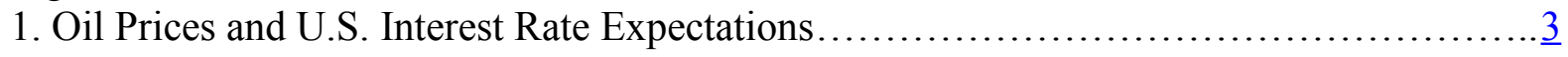

2. Macroeconomic Variables.................................................

3. Bank-Level Variables..................................................... $\frac{7}{8}$

4. Distribution of Non-Performing Loan Ratio in Saudi Arabia......................... $\underline{8}$

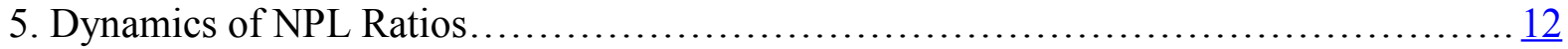

6. Oil-Macro-Financial Feedback Effects, Baseline Specification......................14

Tables

1. Variable Description and Unitroot Test P-Values...................................

2. Determinants of Bank NPLs in Saudi Arabia........................................ 


\section{INTRODUCTION}

Oil prices have fallen significantly since mid-2014 and the U.S. Federal Reserve is expected to continue raising its policy rate at a measured pace (Figure 1). Brent crude oil prices dropped by 60 percent to $\$ 46$ a barrel by January 2015 . They rebounded more than 40 percent through May but have declined to $\$ 37$ a barrel by early-January 2016 . The U.S. Federal Reserve delivered a widely-anticipated 25 basis point interest rate "lift-off" in December 2015. Market participants expect the Fed Funds rate may increase by a total of 50-60 basis points in the coming 12 months.

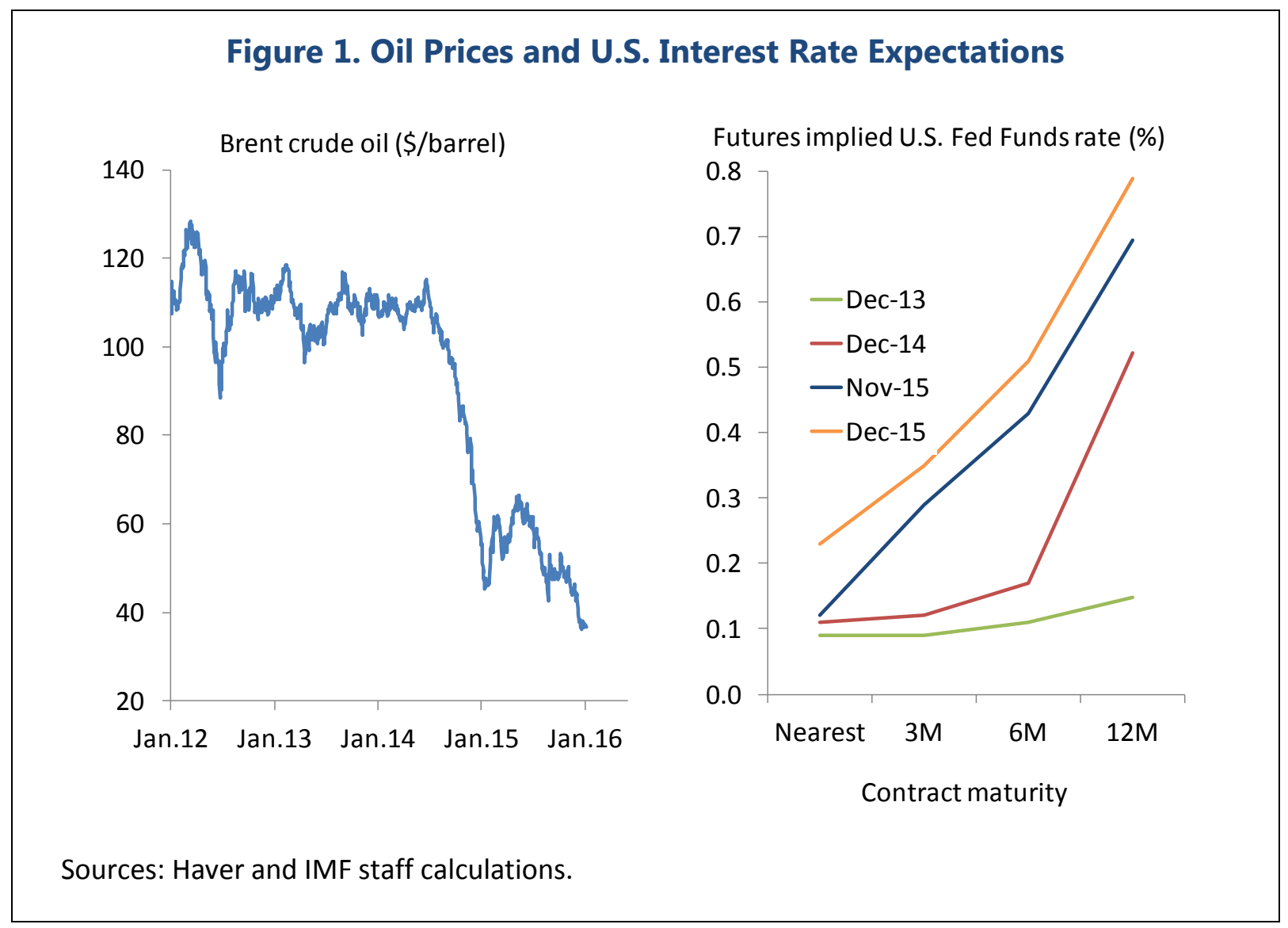

These are key developments for Saudi Arabia given the importance of oil to the economy and the peg of the Saudi Arabian riyal to the U.S. dollar. Non-oil revenues have increased in importance, reflecting in part the authorities' efforts to diversify the economy. However, oil revenues continue to account for a large share of central government fiscal revenues and export revenues. The oil sector comprises nearly $1 / 2$ of overall GDP. Further, activity in the non-oil sector is correlated with oil prices through government spending. Saudi Arabia has pegged the riyal to the U.S. dollar at a parity of 3.75 since 1986 . Given the fixed exchange rate regime and relatively open capital account, the expected increase in U.S. interest rates in the coming months would prompt the Saudi Arabian Monetary Agency (SAMA) to raise its policy rate despite lower oil revenues putting a damper on economic activity. 
To be sure, the banking system in Saudi Arabia appears strong and resilient to shocks. Commercial banks in Saudi Arabia are profitable, liquid, and well-capitalized. According to Financial Soundness Indicators (Q3 2015), on average, NPLs were low at 1.2 percent of gross loans, the capital adequacy ratio was high at 17.8 percent, and NPLs were provisioned comfortably by nearly twice their amount. Overall, corporate balance sheets are in good shape. The Saudi Arabian Monetary Agency (SAMA)'s regulation and supervision of the banking system has continued to strengthen in recent years, including through the early adoption of Basel III capital and liquidity standards.

Nonetheless, the developments discussed above can propagate through the domestic financial system and feed back to the real economy. The literature studies such "macro-financial linkages" by exploiting both macroeconomic and bank-level balance sheet data. One approach is to examine the determinants of bank solvency risk represented by nonperforming loans (NPLs) using multivariate frameworks. This can be done by using country-level data alone or exploiting bank-level data at the same time. Nkusu (2011) analyzes country-level data spanning 1998-2009 for 26 advanced economies and confirms that adverse macroeconomic developments are associated with rising NPLs. De Bock and Demyantes (2012) use country-level annual observations for 25 emerging markets during 1996-2010 and find that the NPL ratio increases when economic growth declines, the exchange rate weakens, the terms of trade deteriorates and debt-creating capital inflows decline. Klein (2013) uses data spanning 1998-2011 for the ten largest banks in 16 countries (thus a total of 160 banks) in Central, Eastern and South-Eastern Europe and finds that macroeconomic conditions are relatively more important than banks specific factors in explaining NPLs.

Studies focusing on the Middle East and North Africa region include Espinoza and Prasad (2010) which was the first attempt to model NPLs in the GCC countries using both macroeconomic and bank-level data. Using data spanning 1995-2008 for about 80 banks in the GCC region, the authors find that the NPL ratio rises as economic growth declines and both interest rates and risk aversion increase. Love and Ariss (2014) analyze a panel of Egyptian banks over 1993-2010 and find that both larger capital inflows and stronger GDP growth improve bank loan portfolio quality.

Another modeling approach is to examine the presence of feedback effects among bank solvency risk, broader bank balance sheet conditions, and the macroeconomy using a panel vector autoregression (VAR) approach. Earlier work relies on macro-level data, including one by Nkusu (2011) who finds that a sharp increase in NPLs triggers long-lasting negative effects on macroeconomic performance. De Bock and Demyantes (2012) find that economic activity slows when NPLs increase or credit contracts. Klein (2013) argues based on his panel VAR results that strong feedback effects run from the banking system to the real economy. Espinosa and Prasad (2010) study the GCC economies and find a strong, albeit short-lived feedback effect from weaker bank balance sheet conditions to economic activity. 
Studies applying a panel VAR approach to bank-level data are emerging. Early work includes Marcucci and Quagliariello (2008), who use bank level data for Italy in estimating a panel VAR model. They find evidence supporting a bi-directional feedback loop between the banking sector and the macroeconomy. Love and Ariss (2015) use bank-level data in their panel VAR model to find macro-financial linkages in Egypt.

This paper builds on the emerging literature using both macroeconomic and bank-level data to study oil-macro-financial linkages in Saudi Arabia. First, key determinants of bank NPLs are identified using a multivariate panel model while controlling for bank specific effects. Second, a panel VAR framework developed by Love and Zicchino (2006) is employed to assess feedback effects among macroeconomic and bank level balance sheet variables. To our knowledge, this paper represents the first attempt to apply a panel VAR framework to a GCC country's macroeconomic and, importantly, bank-level data.

Econometric results suggest the presence of oil-macro-financial linkages in Saudi Arabia. A multivariate regression approach reveals that bank-level NPLs increase when oil price growth and economic activity decline. Movements in U.S. interest rates, however, do not systematically affect NPLs. A panel VAR analysis reveals a feedback loop among bank solvency risk (NPLs), liquidity in the economy (credit) and banking system (deposits), and broader economic activity (nonoil private sector GDP growth).

The results should be interpreted with a range of caveats in mind. First, the information content of publicly available bank-level balance sheet data is relatively limited. Second, any analysis based on historical data might not always account for the effects of recent changes in policy frameworks. Third, the data spanning 1999-2014 may not capture a sufficient number of oil price and financial cycles. Fourth, there is considerable parameter uncertainty surrounding the estimated relationship between macroeconomic shocks and NPL ratios.

The rest of the paper is organized as follows. Section II describes data. Section III discusses methodologies and results. Section IV checks robustness of key findings and Section V concludes.

\section{DATA}

A range of variables were considered based on Saudi Arabia's characteristics and guided by the literature. Historically, NPLs seem to have been influenced by oil prices, government spending, and growth in the non-oil sector. Sustained low oil prices would over time lead to fiscal tightening and reduce the growth rates of nonoil private sector GDP and real credit extension. As economic activity moderates, equity prices would decline, increasing banking sector leverage and the banks' riskiness. Lower equity prices also create negative wealth effects, as documented in the literature, even though the magnitude in emerging markets 
tends to be smaller than those in advanced economies. ${ }^{2}$ As a result, the creditworthiness of borrowers would worsen and liquidity conditions tighten, increasing bank NPLs. Domestic interest rates would increase as the U.S. starts to tighten monetary policy, raising borrowing costs which could put additional pressure on asset quality. On the liquidity side, deposits have historically been affected by oil prices-lower oil prices reduce income and deposit inflows, or even trigger a draw down, particularly by companies most affected by the price drop.

\section{Figure 2. Macroeconomic Variables}
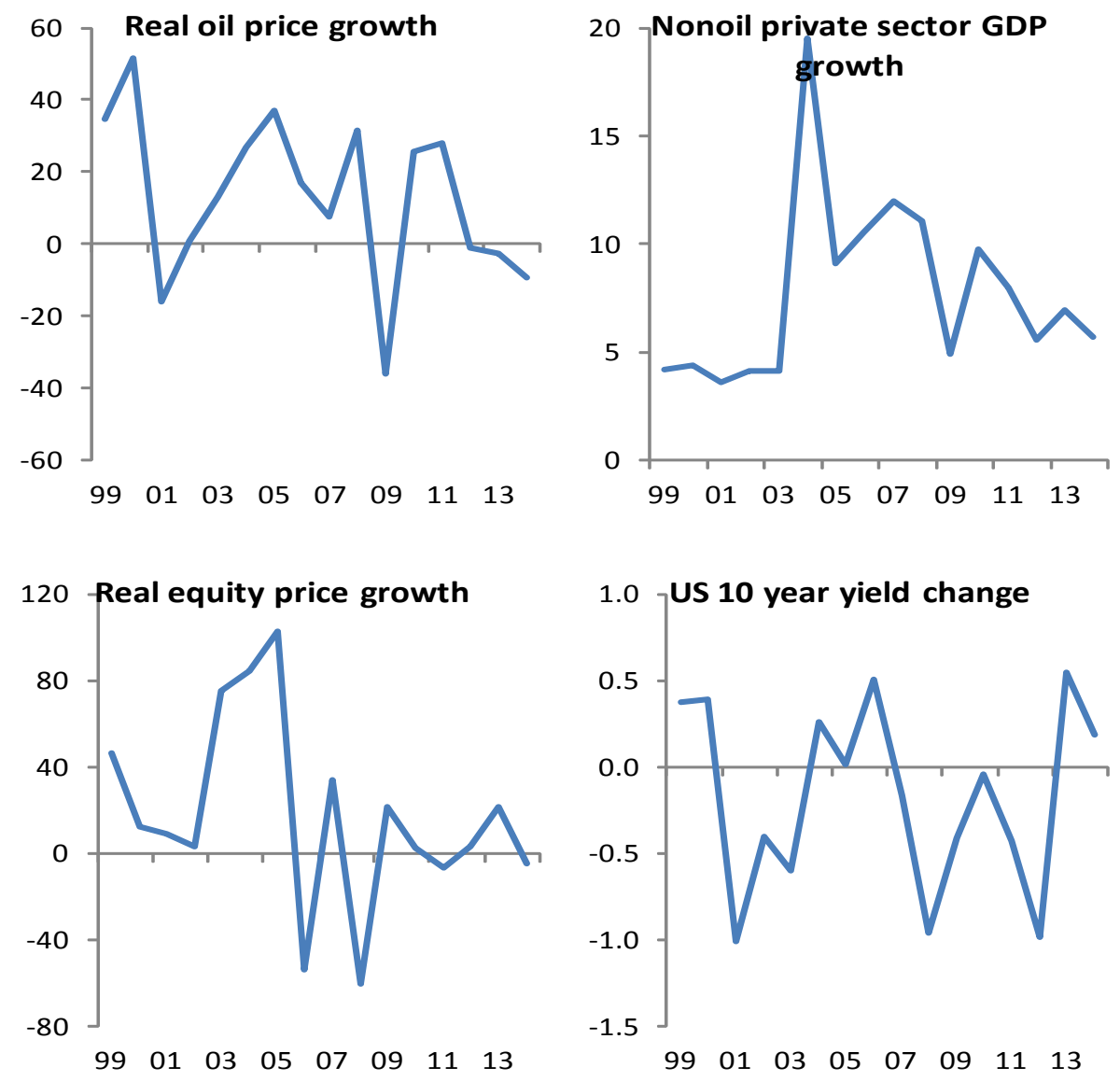

Source: Haver

\footnotetext{
${ }^{2}$ Funke (2004) uses a panel of 16 emerging markets and finds a small but statistically significant stock market wealth effect. Cho (2006) finds stock market wealth effect in Korea for the highest income bracket households who typically hold a large share of corporate stock. Peltonen et al (2012) analyze a panel of 14 emerging economies and find that the wealth effect on consumption is stronger for countries with higher stock market capitalization. See Hesse (2008) for a summary. Market capitalization in Saudi Arabia was somewhat below 80 percent of GDP in 2014, considerably below the 100-370 percent of GDP witnessed during 2004-08, but comparable to the ratio for other GCC countries at present.
} 
Figure 3. Bank-Level Variables
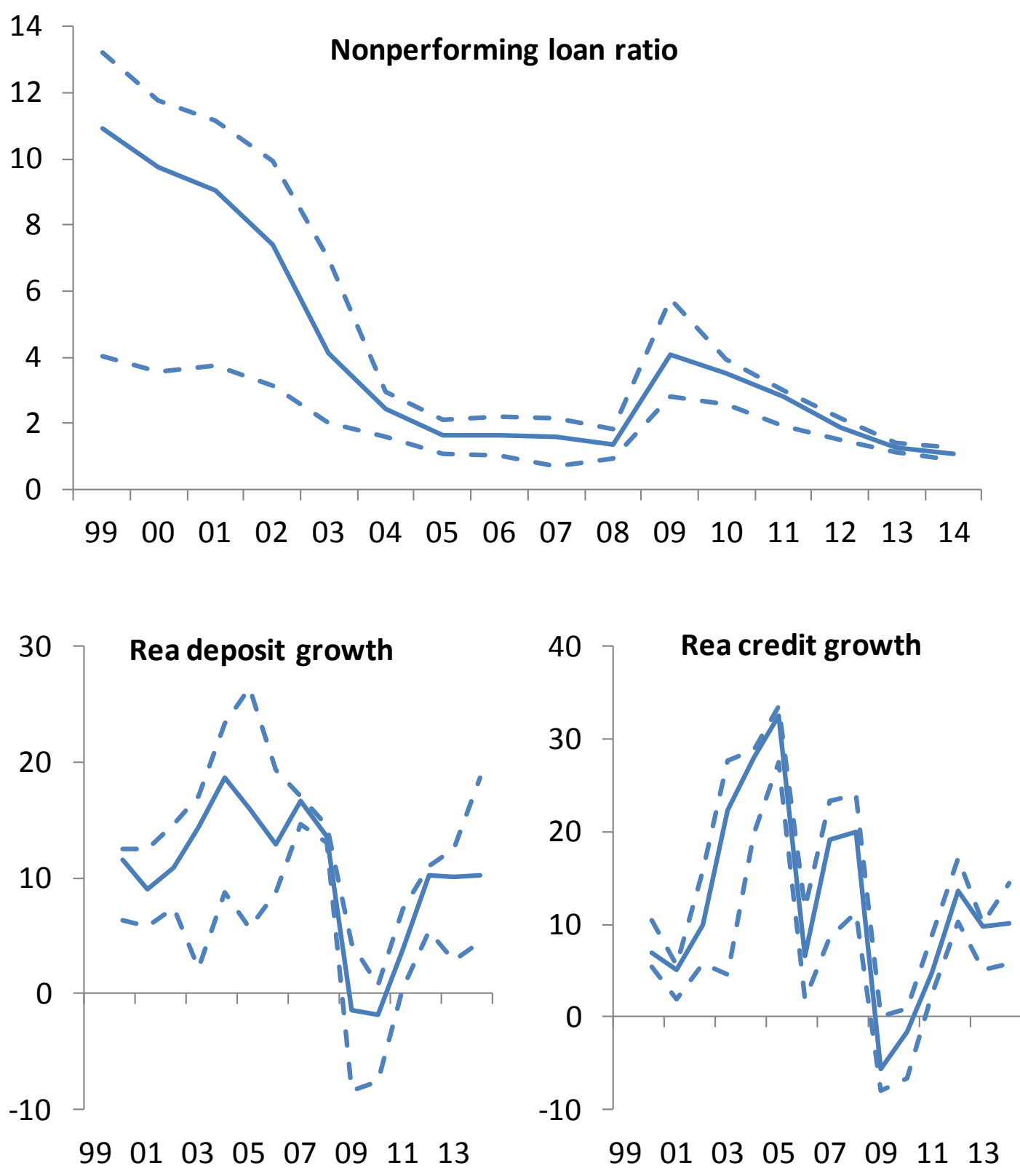

Source: Bankscope and the author's calculations. Note: Dashed lines represent a 50 percent range.

The macroeconomic variables include real oil price growth, nonoil private sector real GDP growth, real equity price growth, and US bond yields (Figure 2). Data is annual for the period 1999-2014. Real oil price growth averaged 17 percent year-on-year during 1999-2011 despite having declined sharply in 2001 and 2009. More recently, it fell increasingly into 
negative territory, reaching close to -10 percent in 2014 . Nonoil private sector real GDP growth jumped in 2004, from around 4 percent year-on- year on average during the preceding several years to near 20 percent and, despite decelerating, remained above 10 percent through 2008. However, as lower oil prices have taken their tall on economic activity, growth performance fell to below 6 percent in 2014. Stock returns were impressive during the earlier part of the sample period on strong oil price performance. Real equity price growth remained 75-100 percent year-on-year during 2003-05. However, following a sharp 50 percent drop in 2006, stocks returns remained more subdued and registered a 5 percent decline in 2014. U.S. 10-year bond yields declined from 5.5-6 percent to 2.5 percent during the sample period, representing an annual average decline of 17 basis points.

Housing prices are important but not considered due to lack of data. The exchange rate is not included as foreign currency exposures of the domestic financial system are small and the riyal is pegged to the US dollar.

\section{Figure 4. Distribution of Non-Performing Loan Ratio in Saudi Arabia}

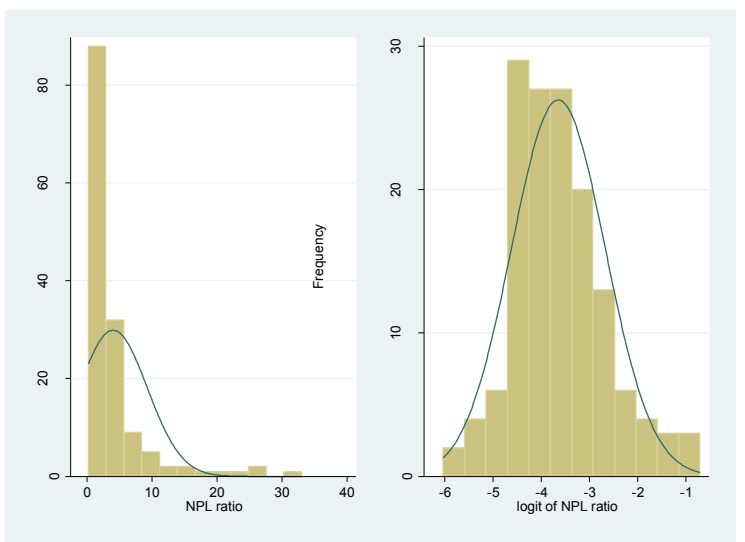

Sources: Bankscope and the author's calculations.

The bank-level variables include NPLs as a share of total loans (the NPL ratio), real credit growth, and real deposit growth (Figure 3). The analysis relies on publicly available bank-bybank data on balance sheets and profit/loss accounts from Bankscope, focusing on 9 banks for which sufficient data are available for 1999-2014. The NPL ratio broadly declined during the sample period, from an average of 11 percent to close to 1 percent. The pace of decline accelerated during the first half of the 2000s when oil price strengthened noticeably. The NPL ratio increased in 2009, coinciding with a sharp oil price decline, but also with defaults of two large family-owned conglomerates due to events likely unrelated to the decline in oil prices. Credit growth appears to broadly mirror movements in oil prices, economic activity and equity prices. Deposit growth was relatively more stable and averaged 14 percent yearon-year in real terms through 2008, but moderated to around 10 percent during 2012-14. 
Following the literature that considers solvency risk, the NPL ratio is logit-transformed, that is, $\log (x / 1-x)$, so that the variable is distributed more normally, and captures the empirical regularity that NPL ratios tend to vary most for banks that start out with higher starting levels (Figure 4).

We use the variables either in differences or ratios to help alleviate concerns that the variables may contain unit roots. Furthermore, unit root tests (panel unit root tests for bank level variables) are conducted to check the variables' statistical property (Table 1). Fisher Augmented Dickey-Fuller and Fisher Phillips-Perron tests of unit roots are designed to test the null hypothesis that all series are non-stationary against the alternative hypothesis that at least one of the series in the panel is stationary. These tests do not require a balanced sample and therefore do not reduce the time dimension of the data. Both tests reject the null hypothesis for most variables. For three variables, at least one of the tests rejects the null hypothesis. Given these results we consider all variables as stationary (Love and Ariss (2014)).

\begin{tabular}{|llll|}
\hline \multicolumn{4}{|c|}{ Table 1. Variable Description and Unit Root Test P-Values } \\
\hline Variable & Description & Augmented dickey fuller & Phillips-Perron \\
\hline Macro variables & & \\
oilg & & \\
$y g$ & Real oil price growth & 0.0113 & 0.0071 \\
eqg & Nonoil private GDP growth & 0.9451 & 0.0494 \\
us & Real equity price growth & 0.0782 & 0.0000 \\
Bank level variables & US bond yields, change & 0.0215 & 0.0167 \\
$n p l r$ & & & \\
logit_nplr & & & \\
crg & NPL ratio & 0.0000 & 0.0045 \\
dpg & NPL ratio, logit & 0.0459 & 0.6987 \\
\hline Sources: Bankscope, Haver, and the author's calculations. & 0.0315 & 0.0000 \\
\hline
\end{tabular}

\section{Methodologies AND RESUltS}

We follow the literature - such as Espinoza and Prasad (2010) and Love and Ariss (2014) and employ two closely related regression frameworks to assess oil-macro-financial linkages in Saudi Arabia. As a first step, a multivariate model is estimated to identify determinants of bank-level NPL ratios. Second, a panel VAR model is estimated to assess the impact of macroeconomic shocks on bank balance sheets, a positive feedback loop within bank balance sheets, and the effects of bank balance sheet conditions to vis-a-vis the macroeconomy. 


\section{A. Solvency Risk}

The determinants of the NPL ratio are estimated using the following multivariate panel data specification for bank $i$ in year $t$.

$$
\begin{aligned}
\operatorname{logit}_{N P L r_{i t}}= & \alpha_{1} \operatorname{logit}_{N P L r_{i, t-1}}+\sum_{j} \alpha_{2 j} \text { Macro }_{j, t-1}+\sum_{k} \alpha_{3} \text { Bank }_{k, i, t-1} \\
& +\alpha_{4} \text { dummy }_{08 / 09}+\theta_{i}+\varepsilon_{i, t}
\end{aligned}
$$

where logit_NPLr $_{i t}$ is the logit transformation of the ratio of nonperforming loaks to total loans and the lagged regressor $\operatorname{logit}_{-} N P L r_{i, t-1}$ captures its persistence commonly found in the literature. Macro $_{j, t-1}$ represents three variables $(j=1,2,3)$ - real growth rates of oil

prices, nonoil private sector GDP, and equity prices, which are all lagged by one period. NPL ratios are expected to decline as the value of these variables increase. Bank $k_{k, i, t-1}$ is real credit growth $(k=1)$ lagged by one period. Positive and healthy credit growth would help support economic activity and lead to lower NPL ratios. That being said, in the medium term, higher leverage in the economy could build vulnerabilities. Time dummy variables dummy $_{08 / 09}$ where were introduced in the regressions to control for events other than oil price developments that potentially led to an increase in NPL ratios around the time of the global financial crisis. In particular, two large family-owned conglomerates defaulted on loans in 2009 due to events unrelated to the decline in oil prices.

Equation (1) is estimated using both fixed effects and system Generalized Method of Moments (GMM) approaches. The later was proposed by Arellano and Bover (1995) and Blundell and Bond (1998). The NPL ratio exhibits a strong autocorrelation and the data's time series dimension is short relative to its cross-sectional dimension. Compared to a GMM estimation approach, a fixed effects approach suffers from a downward Nickell bias in such circumstances. To help reduce the number of instruments and avoid over-fitting the model, we follow Roodman (2007) and limit lag depth and "collapse" the matrix, or drop zeros from the instrument matrix.

NPLs in Saudi Arabia appear to be driven by oil prices and nonoil private sector growth (Table 2). The NPL ratio exhibits strong auto-correlation, and the coefficients are smaller for fixed effects models, suggesting the existence of Nickell bias. The growth rates of real oil prices and nonoil private sector real GDP are key determinants of bank-level NPL ratios. U.S. interest rates do not directly affect NPL ratios in a systematic way-the coefficients vary in terms of size, sign and statistical significance across models. When regressed together with the growth rates of real oil prices and nonoil private sector GDP, the coefficients of real equity price growth are statistically significant only in one specification while those on banklevel real credit growth are not statistically significant. The 2008/09 time dummy is significant across all specifications. 


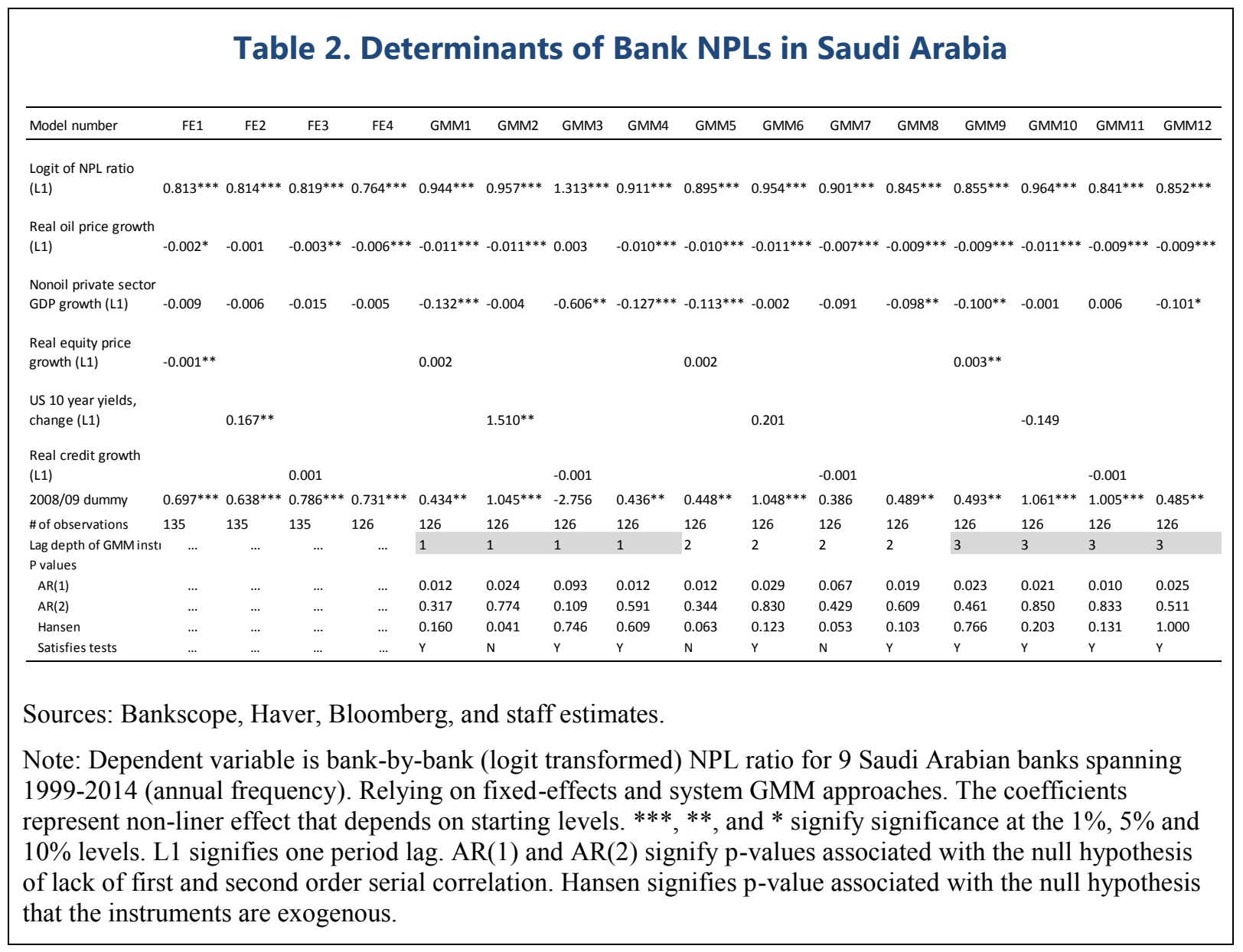

The recent decline in oil prices and attendant slowing of economic activity could therefore lead to an increase in the NPL ratio (Figure 5). For illustrative purposes, we take the NPL ratio of 1 percent, the average of sampled Saudi banks in 2014, and a somewhat higher 2.5 percent as starting points and apply the coefficients obtained in the regressions. We assume oil prices decline by 50 percent and non-oil private sector real GDP growth falls by 2 percentage points in $t=0$, and remain unchanged for the rest of the simulation period. Figure 5 shows that, starting from 1percent, the NPL ratio would rise by more than 1 percentage point to 2.4 percent in three years. Banks with lower asset quality would witness larger increases. Starting from 2.5 percent, the NPL ratio would rise by 3.5 percentage points to 6 percent. 
Figure 5. Dynamics of NPL Ratios

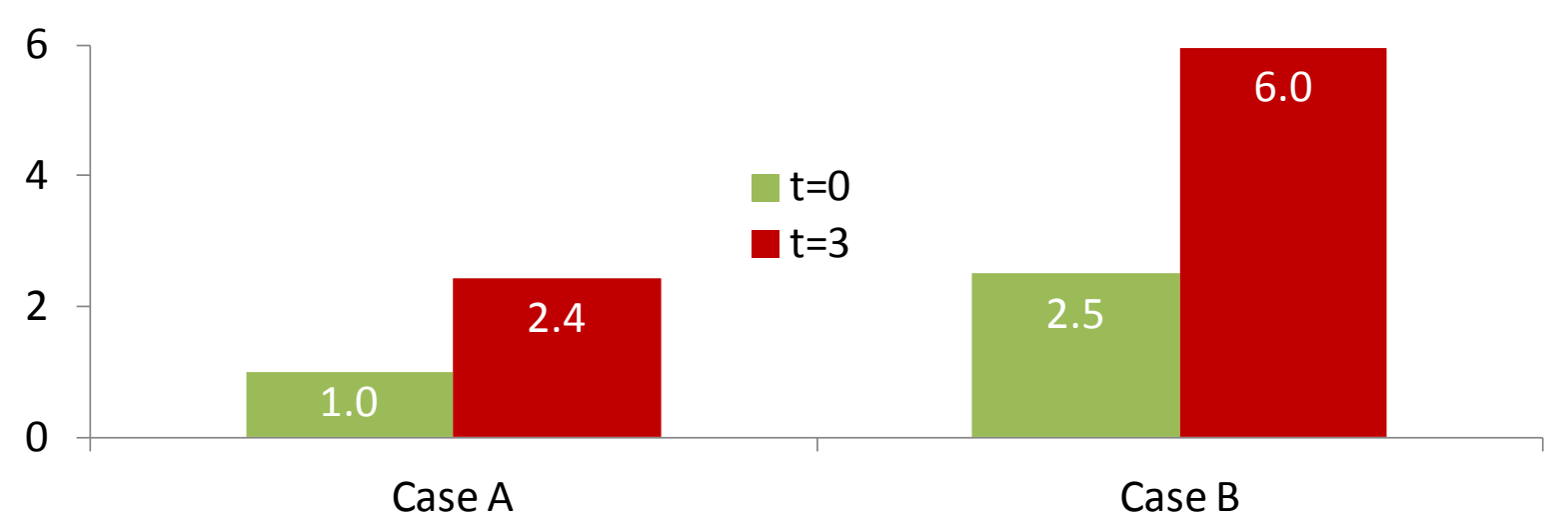

Source: The author's calculations.

Note: After a 50 percent decline in oil prices and 2 percentage point reduction in nonoil private sector real GDP growth in $\mathrm{t}=0$.

\section{B. Oil-macro-financial linkages}

In a bid to identify feedback loops between the macroeconomic and bank level variables, the multivariate analysis above is extended into a panel autoregression (VAR) model which accounts for bank-level heterogeneity.

$$
y_{i, t}=B_{0}+B_{1}(L) y_{i, t}+u_{i, t}
$$

where $y_{i, t}$ is a vector of macroeconomic and bank-level variables, $B_{0}$ is the deterministic component, $(L)$ is a lag operator and $u_{i, t}$ is the residual. The model was estimated using the pvar routine developed by Love and Zicchino (2006), which exploits a system-based GMM estimator as in Arellano and Bover (1995). ${ }^{3}$

The identification of shocks is based on a Choleski decomposition where the variables are stacked to explore how macroeconomic shocks affect bank-level variables first, and how the latter affect the former in the second round. In particular two macroeconomic variables \{real oil price growth (oilg), nonoil private sector GDP growth (yg)\} are stacked at the top. To allow space for bank-level variables, real equity price growth was dropped from the baseline specification on the grounds that the variable did not come out as consistently significant in

\footnotetext{
${ }^{3}$ As the fixed effects are correlated with the regressors due to lags of the dependent variables, the meandifferencing procedure commonly used to eliminate fixed effects would create biased coefficients. The orthogonality between transformed variables and lagged regressors is preserved by forward mean-differencing (the Helmert procedure in Arellano and Bover, 1995), which removes the mean of the future observations. Then, lagged regressors are used as instruments to estimate the coefficients by system GMM.
} 
the previous section as nonoil private sector GDP growth. The potential role of equity price performance in creating oil-macro-financial feedback effects will be explored as part of robustness check.

The bank-level variables \{NPL ratio (nplr), real deposit growth (crg), real credit growth $(d p g)\}$ are stacked below the macro-level variables. ${ }^{4}$ The ordering is guided by the perceived "sluggishness" of the variables. Real growth rates of credit and deposits are included to help capture as much as possible balance sheet conditions. In particular, deposits help integrate in the feedback loop bank liquidity risks-higher riskiness of a bank (eg due to high NPLs) would prompt customers to withdraw deposits, increasing liquidity risk for the bank, which would further aggravate the bank's solvency risk. The potential impact of different ordering will be explored as part of robustness check.

Interactions between real and financial factors are important in a changing oil price environment in Saudi Arabia (Figure 6). First, consistent with the results reported in the previous section, NPL ratios rise after the real growth rates of oil prices and non-oil private sector GDP decline (the latter through lower credit growth). Deposit growth declines as do the growth rates of credit. For example, a 1 percent decline in oil prices leads to a $0.1-0.15$ percentage point rise in the NPL ratio in the long run. ${ }^{5}$ It also leads to a $0.2-0.3$ percent decline in credit growth, and a 0.1 percent decline in deposit growth (even though the latter is not statistical significant).

Second, there is a feedback effect within bank balance sheets. For instance, a one percentage point increase in the NPL ratio leads to 2-3 percentage point decline in real growth rates of credit and deposits. Moreover, a one percentage point decline in real deposits growth leads to $3 / 4$ of a percentage point reduction in real credit growth. Slower real credit growth weakens nonoil private sector GDP growth, which in turn leads to a rise in the NPL ratio, with both channels operating with a relatively long lag (even though the latter is not statistically significant).

Third, weaker balance sheet conditions adversely affect economic activity. A one percentage point reduction in real credit growth leads to a $0-0.1$ percentage point decline in nonoil private sector GDP growth. A one percentage point rise in the NPL ratio dampens nonoil private sector GDP growth by $3 / 4$ of a percentage point.

\footnotetext{
${ }^{4}$ Our panel VAR model does not yield plausible results when logit transformed NPL ratios are used. Therefore we used un-transformed NPL ratios.

${ }^{5} 0.02 /(1-0.85)=0.13$ where 0.85 is the autoregressive coefficient of the NPL ratio.
} 
Figure 6. Oil-Macro-Financial Feedback Effects, Baseline Specification

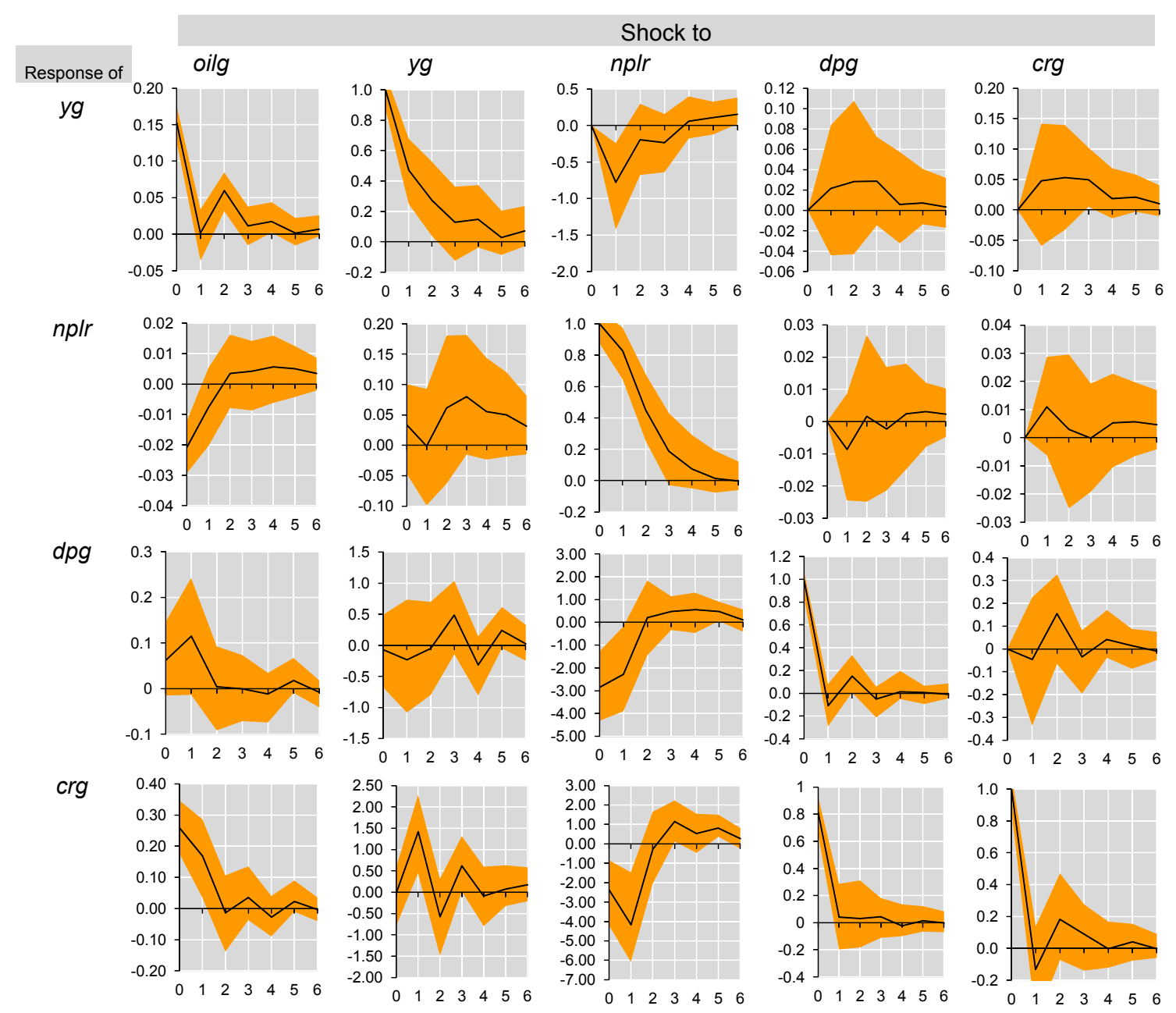

Source: The author's calculation.

Note: oilg is real oil price growth, $y g$ is real nonoil private sector GDP growth, $n p l r$ is NPL ratio, $d p g$ is real deposit growth, $\mathrm{crg}$ is real credit growth.

\section{Robustness}

To check the robustness of the key findings, we first examine whether the results change when bank-level variables are ordered differently. Second, real equity price growth is included in the panel VAR system.

\section{A. Different Variable Ordering}

Does the particular ordering dictate our key findings in the previous section? Based on the assumption that oil price developments are (weakly) exogenous to the economy and GDP growth is weakly exogenous to the banking system, we focus on the ordering of the bank level variables. In particular, three different variations are experimented with. First, the NPL ratio is stacked at the bottom by swapping its position with real credit growth such that $\{\mathrm{crg}$, 
$d p g, n p l r\}$ (pvar 2). Second, real deposit growth is stacked at the bottom such that $\{\mathrm{crg}, n p l r$, $d p g\}$ (pvar 3). Finally, real credit growth is stacked in-between such that $\{n p l r, c r g, d p g\}$ (pvar 4).

The impulse response functions in the annex suggest that the results remain broadly robust to different variable ordering (Figures A1-A3). However, the results also warn that the role of the NPL ratio in creating a feedback loop could be greater than the one suggested by the baseline results discussed in Section III. When the NPL ratio is stacked at the bottom to allow contemporaneous response to all other variables, such that $\{\mathrm{crg}, d p g, n p l r\}$ (pvar 2), following a one percentage point decline in real credit growth or real deposit growth, the NPL ratio increases by $0.1-0.2$ percentage point and about 0.3 percentage point, respectively, in the long run. An increase in the NPL ratio leads to a reduction in real growth rates of non--oil private sector GDP, credit, and deposits. This contrasts with the baseline results where the NPL ratio does not respond to a shock to credit growth nor to that to deposit growth.

\section{B. Feedback Through Asset Prices}

Can the baseline results be biased due to lack of asset price variables which can play a key role in oil-macro-financial linkages in Saudi Arabia? To see this, nonoil private sector GDP growth is replaced by equity prices, a variable that has been found a key determinant of NPLs in the literature (Espinoza and Prasad (2010), Nkusu (2011), Beck et al (2013)). Lower equity prices increase leverage on bank balance sheets and the bank's riskiness. Moreover, the literature documents the existence of the wealth effect stemming from stock market valuation changes to consumption and investment in emerging markets (Cho (2006), Funke (2004), Peltonen et al (2012)). To this end, the potential role of equity price performance in oil-macro-financial linkages is examined again by estimating a panel VAR model with real equity price growth. Nonoil private sector GDP growth is dropped to reduce variable count. The variables are stacked as \{oil, nplr, dpg, crg, eqg\} (pvar 5).

Two key messages emerge from the results (Figure A4). First, most importantly, the main message from the baseline model remains unchanged. Thus the baseline specification does not suffer from omitted variable problem with respect to equity prices. Second, the results reveal that equity prices work as a transmission channel of the oil-macro-financial feedback loop. A one percentage point reduction in oil price growth leads to a 0.6 percentage point decline in real equity price growth, which in turn leads to a higher NPL ratio and lower real credit growth, both by a $1 / 2$ of one percentage point. Lower credit growth prompts a further decline in equity performance. 


\section{Conclusion}

The existence of oil-macro-financial linkages in Saudi Arabia was examined using two closely related regression approaches - a panel multivariate model and a panel vector autoregression model - and both macroeconomic and bank-level data. First, results from a panel multivariate model revealed that lower growth rates of oil prices and non-oil private sector GDP lead to a rise in NPL ratios, representing higher bank solvency risk. Second, results from a panel VAR model suggested that higher weaker macroeconomic conditions (lower growth of oil prices and non-oil private sector GDP) lead to weaker bank balance sheet conditions (higher NPL ratios, lower deposit and credit growth), which feedback to further weaken macroeconomic conditions.

This paper contributes to the emerging literature exploring micro-level information in estimating a panel VAR model (Love and Ariss (2014) study Egyptian banks). In particular, this paper represents the first attempt to apply a panel VAR framework to a GCC country while exploiting both macroeconomic and bank-level data. Our work can be extended to a larger set of GCC banks, similar to a study by Espinoza and Prasad (2010), while exploiting bank-level information to assess oil-macro-financial linkages in a panel VAR framework. 


\section{ANNEX}

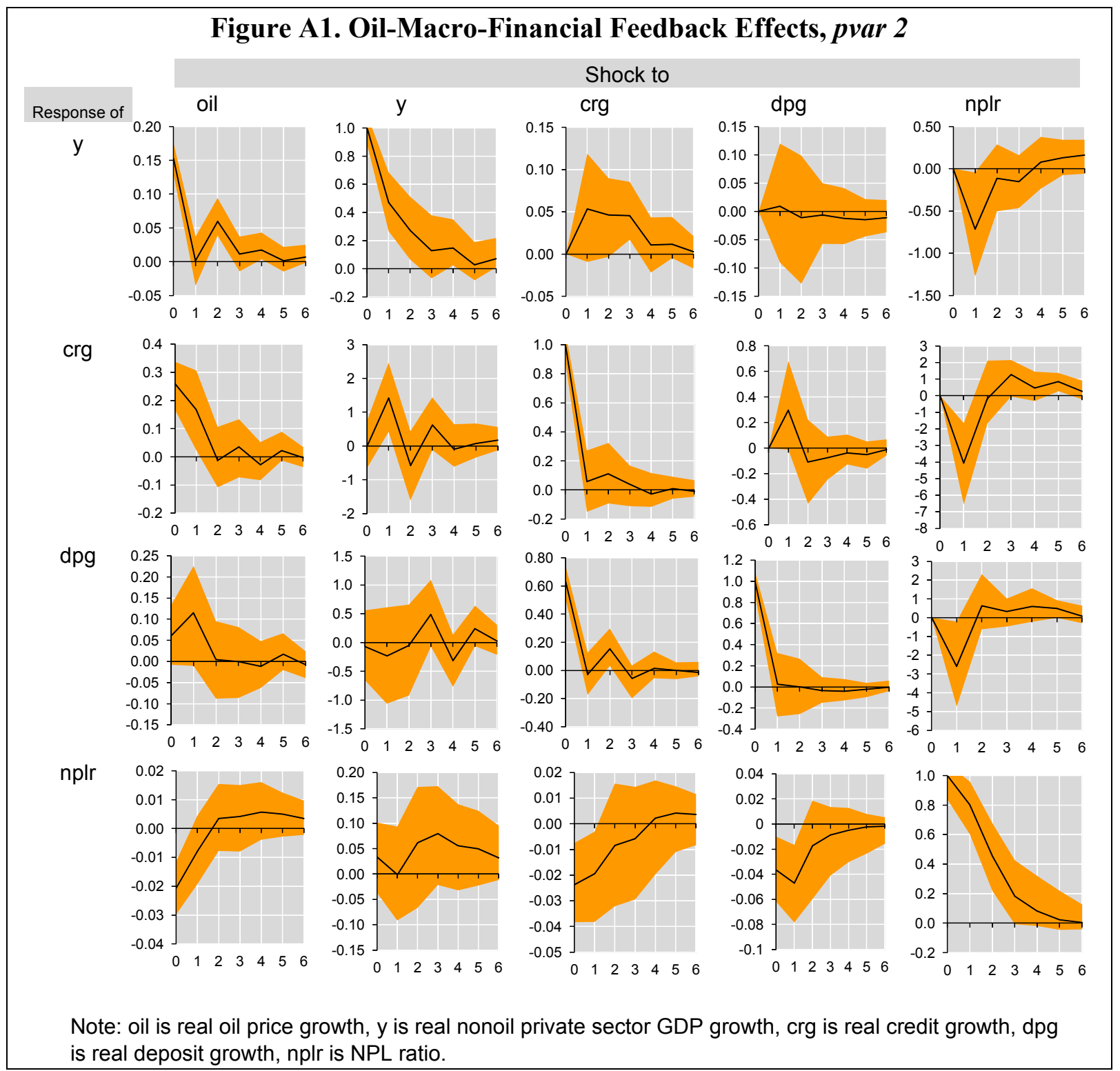




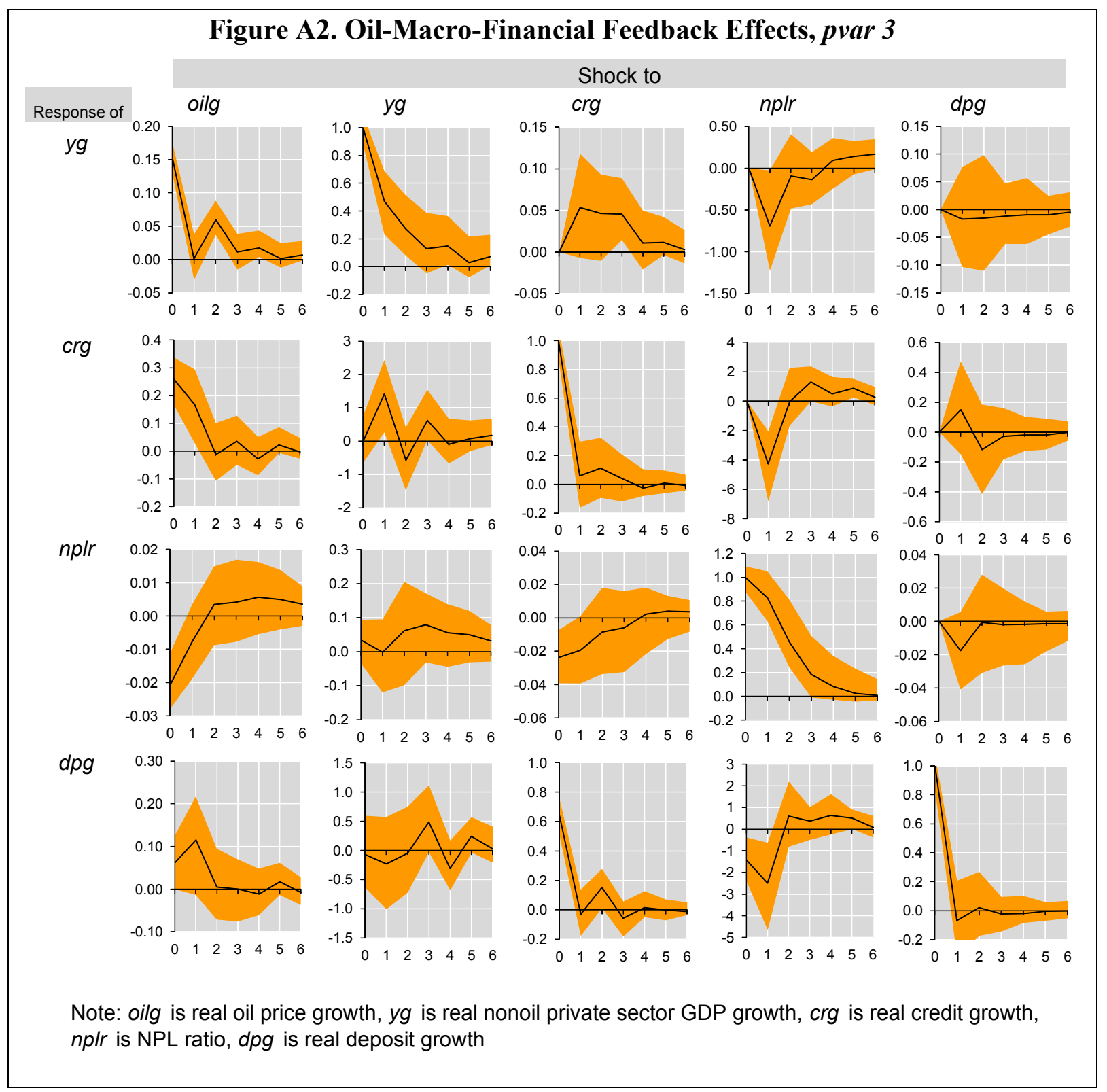




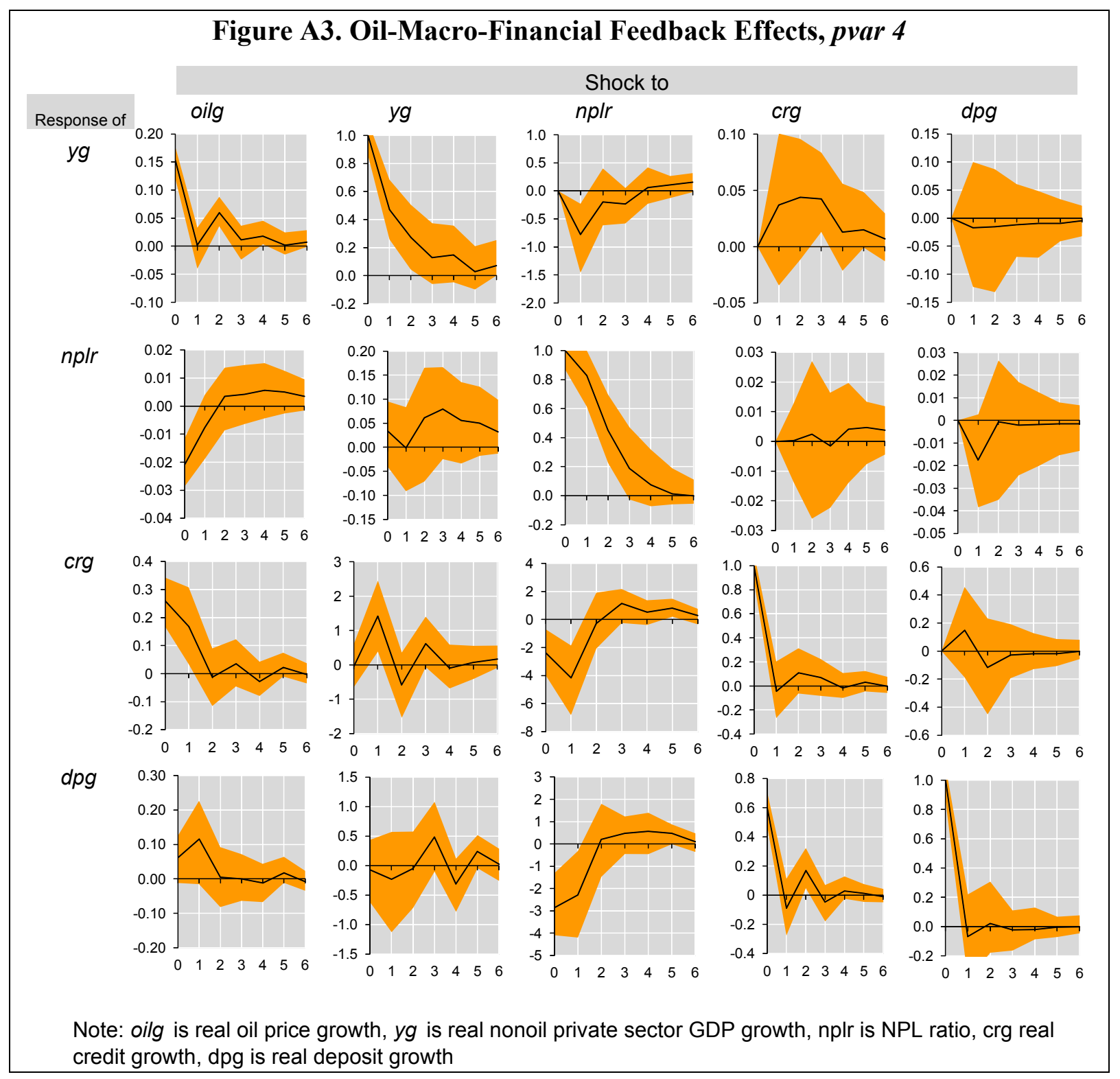

CInternational Monetary Fund. Not for Redistribution 


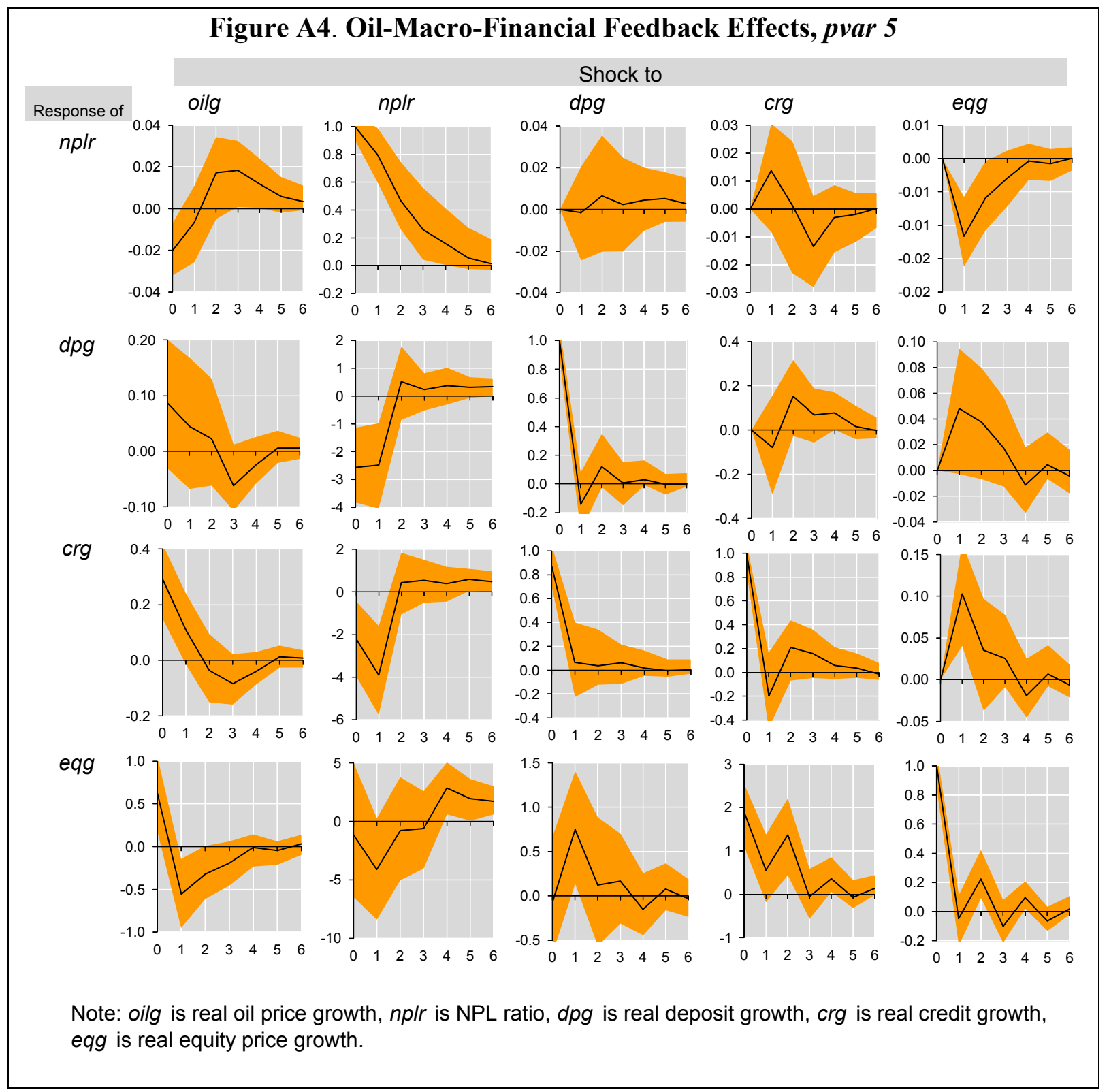




\section{REFERENCES}

Arellano, M., and O. Bover (1995). "Another look at the instrumental variable estimation of error-components models," Journal of Econometrics, 68 (1), pp 29-51.

Beck, R., P. Jakubik, and A. Piloiu (2013). "Non-performing loans what matters in addition to the economic cycle?" ECB Working Paper 1515.

Blundell, R. and S. Bond (1998). "Initial conditions and moment restrictions in dynamic panel data models," Journal of Econometrics, 87, pp 115-43.

Cho, S. (2006). "Evidence of a stock market wealth effect using household level data," Economic Letters, 90, pp 402-6.

De Bock, R., and A. Demyanets (2012). "Bank Asset Quality in Emerging Markets: Determinants and Spillovers," IMF Working Paper 12/71.

Espinoza, R., and A. Prasad (2010). "Nonperforming Loans in the GCC Banking Systems and their Macroeconomic Effects," IMF Working Paper 10/224.

Funke, N. (2004). "Is there a stock market wealth effect in emerging markets?, " Economic Letters, 83, pp 417-21.

Hesse, H. (2008) "Stock market wealth effects in emerging market countries," VOX blog: http://www.voxeu.org/article/stock-market-wealth-effects-emerging-market-countries

Klein, N. (2013). "Non-Performing Loans in CESEE: Determinants and Impact on Macroeconomic Performance," IMF Working Paper 13/72.

Love, I., and R. T. Ariss (2014). "Macro-financial linkages in Egypt: A panel analysis of economic shocks and loan portfolio quality," Journal of International Financial Markets, Institutions and Money, 28 (C), pp 158-81.

Love, I., and L. Zicchino (2006). "Financial development and dynamic investment behavior: evidence from panel vector autoregression," The Quarterly Review of Economics and Finance, 46, pp 190-210.

Marcucci, J., and M. Quagliariello (2008). "Is bank portfolio riskiness procyclical? Evidence from Italy using a vector autoregression," Journal of International Financial Markets, Institutions and Money, 18, pp 46-63.

Miyajima, K. (2015). “Assessing the resilience of Saudi banks to weaker economic conditions," IMF Country Report No 15/286.

Nkusu, M. (2011). "Nonperforming Loans and Macrofinancial Vulnerabilities in Advanced Economies,” IMF Working Paper 11/161. 
Peltonen, T. A., R. M. Sousa, and I. S. Vensteenskiste (2012). "Wealth effects in emerging market economies," International Review of Economics and Finance, 24, pp 155-66.

Roodman, D. (2009). "A Note on the Theme of Too Many Instruments," Oxford Bulletin of Economics and Statistics, 71 (1), pp 135-58. 